\section{HEGEL'S IMPLICIT VIEW ON HOW TO SOLVE THE PROBLEM OF POVERTY:}

\section{The Responsible Consumer and the Return of the Ethical to Civil Society}

\section{Joel Anderson}

\section{Washington University in St. Louis}

Published in Beyond Liberalism and Communitarianism: Essays on Hegel's "Philosophy of Right," ed. Robert Williams (Albany, NY: SUNY, 2001), 185-205

\begin{abstract}
Against those who argue that Hegel despaired of providing a solution to the problem of poverty, I argue, on the basis of key dialectical transitions in Hegel's Rechtsphilosophie, that he held at least the following: (1) that the chronic poverty endemic to industrial capitalism can be overcome only through changes that must include a transformation in practices of consumption, (2) that this transformation must lead to more sittlich and self-conscious practices of consumption, and (3) that the institution best-suited to enable the development of these more sittlich and self-conscious practices of consumption is the
\end{abstract} Korporation.

Hegel clearly struggled with his views on poverty. His brilliant analyses of pauperization in industrial England and his heart-felt concern for its victims, especially in his lectures on the Philosophy of Right, ${ }^{i}$ stand in stark contrast to his near silence regarding a solution to the problem of poverty. Unlike, for example, the category of crime, poverty is not presented as a necessary evil that is aufgehoben as part of realization of a rational social order. According to Shlomo Avineri's now classic assessment, "...on the problem of poverty, [Hegel] ultimately has nothing more to say than that it is one of the 'the most disturbing problems which agitate modern society'. On no other occasion does Hegel leave a problem at that."i

The lack of an explicit solution to poverty in Hegel's social philosophy has evoked widely varying responses. Some have followed Avineri in viewing this as evidence of Hegel's ability to recognize the unavoidable difficulties for welfare state capitalism. iii Others have seen it
Anderson, "Hegel's Solution to Poverty" 2

as highlighting the exclusionary character of his social philosophy.i ${ }^{\text {iv }}$ In contrast, I shall be arguing that there is a very interesting approach to fighting poverty implicit in Hegel's socia philosophy and suggested by many of his explicit claims.

I shall argue that Hegel held the following view: (1) that the chronic poverty endemic to industrial capitalism can be overcome only through changes that must include a transformation in practices of consumption, (2) that this transformation must lead to more sittlich [ethical] and selfconscious practices of consumption, and (3) that the institution best-suited to enable the development of these more sittlich and self-conscious practices of consumption is the associational institution that Hegel called the Korporation. I am not claiming that Hegel believed that this transformation of consumer practices could actually be brought about. $\mathrm{He}$ certainly made no proposal for doing so. My more limited claim is that the best way to make sense of his writings on poverty is by attributing to him the view that such a transformation was necessary for ending poverty.

To understand the case for this interpretation, it is important to focus on the systematic structure of Hegel's economic and social philosophy. Accordingly, I shall focus on two key dialectical transitions in Hegel's Philosophy of Right. The first is the transition in the notion of "resources" (or "Vermögen") from the economic system based on the "family principle" to that based on the principle of civil society. The second transition is the moment at which civil society's attempts to solve the problem of poverty through colonization, international trade, welfare policies, and industrial regulation reach a point of exhaustion in a moment of "bad infinity." Hegel's account of these transitions provides crucial support for attributing to him the view that ending poverty requires a "return of the ethical [das Sittliche]" into civil society and, especially, into practices of consumption 
1. MODERN POVERTY AND THE RELATIONAL CHARACTER OF "RESOURCES"

In discussing Hegel's view of poverty, it is perhaps best to begin with his rather cryptic summation of the problem of modern poverty:

[D]espite an excess of wealth, civil society is not wealthy enough -- i.e., its own

distinct resources [ihr eigentümlichen Vermögen] are not sufficient -- to prevent an

excess of poverty and the formation of a rabble. [\$245]

This formulation highlights what Hegel sees as the paradox of modern poverty: destitution in the midst of unprecedented wealth. In trying to understand Hegel's position - and his puzzling contrast between "wealth" and "resources" - one should begin by noting that Hegel traces the form and causes of modern poverty (that is, very roughly, poverty under conditions of capitalism) to the fact that, in civil society, one must earn one's livelihood by producing for the everchanging needs of others. If one cannot find buyers in the marketplace -- or if one's employer cannot -- then one will not be able to satisfy one's own needs. As a result of this interdependence, civil society is a domain of profound and universal vulnerability for individuals.

This is in sharp contrast to the economic order out of which civil society emerges, that based on the "family principle." Hegel uses the concept of "family" to designate a form of social relation characterized by immediate, relatively undifferentiated solidarity, particularly economies based on agriculture. There, one consumes what one produces and produces what one needs. In the economic order based on the family principle, one is naturally still vulnerable, but primarily to the vicissitudes of the weather and the soil. The basic productive unit - say, the extended family -- is not dependent on others' desires for its produce. ${ }^{v}$ In the familial economic order, what is needed for livelihood - the "family resources" - is something "permanent and secure", typically, "soil" [\$170; cf. §203, 247]. Once this is in place, families can provide for their simple needs.

The concept of civil society entails something wholly different. For although a member of civil society is in many ways freer and more independent [selbständig], "he cannot accomplish the full extent of his ends without reference to others" $(\S 182 \mathrm{~A})^{\mathrm{vi}}$. In part, this has to do with the industrial mode of production, with the way in which the division of labor puts individuals in a fragile network of interdependence [ $\$ 198]$. But the more fundamental shift is systemic, and has to do with change in the "Vermögen" that is required for a family to provide for itself:

For the families in civil society, property takes on forms other than land, for the needs belonging to civil society become the resources out of which the family creates its satisfied needs. [VPR III: 540]

Since members of civil society no longer produce for their own consumption, they cannot provide directly for their own needs. They have to rely on others to produce the means for the satisfaction of their needs, which they can only obtain if they have something to offer that others need.

As the basis for earning a livelihood, the successful mediation of needs and labor constitutes what Hegel terms the "resources" [Vermögen] distinctive of civil society. ${ }^{\mathrm{vii}}$ Hege distinguishes further between the "particular" resources of an individual (or family) within a society and the "general" resources of the society as a whole. An individual's resources are a function of being appropriately situated within the network of production and consumption, of plugging into this network, of integrating oneself into the interdependent web of supply and demand in such a way that the products of one's labor end up meeting the needs of others. From this perspective, it becomes clear that Hegel's definition of the resources of individuals as "the 
possibility of sharing in the general resources" [\$200] is not to be read in terms of getting one's slice of the economic pie, for that would deny the relational element of Vermögen. ${ }^{\text {vii }}$ Rather, the resources of individuals are constituted by the degree to which they have the opportunity to participate in a well-functioning economy.

Accordingly, the general resources [das allgemeine Vermögen] represent the capacity of a society to provide individuals with the opportunity to earn a living, which depends on the coordination of a fragile network of interdependencies, the "all-round mutual effects of everyone on one another" [VPR IV: 594]. In the Encyclopedia, Hegel speaks of Vermögen as a societal constellation, stating that "this mediation of satistisfaction by the labor of all constitutes the general resources"[Werke 8: §524]. For my purposes, it is important to emphasize that these interconnections comprising societal resources also depend on patterns of consumption: "The endless multiplication of the needs of others is a lasting general resource for everyone."[VPR I:

313]. And more strongly and more optimistically: "No one can take a bite of bread without thereby providing bread for others." [VPR III: 614]. In this relational sense, the needs of others (and, more concretely, their consumer practices) are a resource for all. The point I wish to stress here is that Hegel saw very clearly that the ability of civil society to provide individuals with the opportunity to earn a livelihood depends on the patterns of consumption as much as on the patterns of production. The Vermögen of a society is adequate just in case production and consumption fit into a coherent pattern.

It is in light of this idea that we can make sense of §245, quoted earlier: what is needed in order to avoid mass and chronic unemployment is not wealth as such but rather the dynamic balance of production and consumption that Hegel terms "the resources [Vermögen] distinctive to civil society". Thus, the problem of poverty - or, more precisely, the emergence in wealthy countries of masses of able-bodied people who are unable to provide for themselves and their families - is a problem of coordination. Rather than being generated by shortages or disasters as is the case in premodern economies - the form of poverty with which Hegel is concerned results from the normal functioning of an "unrestricted" [\$243] free market economy.

\section{ECONOMIC LIBERALIZATION AND VULNERABILITY TO THE CONTINGENT}

Of course, there is an additional step in Hegel's argument, which has not yet been mentioned, namely, that in order to achieve a high level of general resources, a society must introduce economic liberalization and allow more room for subjective freedom -- precisely the developments that generate the economic instability that causes modern poverty. Increased subjective freedom and increased individual vulnerability are linked within civil society, in that the primary causes of modern poverty are chronic overproduction and severe imbalances of consumption and production - all of which can be linked to the fact that civil society is the realm of contingency and arbitrariness [Zufälligkeit]. As a result of the liberalization and industrialization of economic relations, there is no longer any guarantee that either the individual producer will be able to participate adequately in the economy or that the overall balance of consumption and production will provide enough jobs.

This raises the thorny issue of the status of subjective freedom within Hegel's economic philosophy. Although much has been made of his commitment to economic liberalization as creating a realm of subjective freedom and individuality, ${ }^{\mathrm{ix}}$ Hegel has serious misgivings, as we shall see, about giving subjective freedom free reign, even in the economic domain. Indeed, everything in the systematic logic of the Philosophy of Right points toward an eventual Aufhebung of the contingency on which subjective freedom is based. ${ }^{x}$ And what drives civil 
society to this supersession of contingency is the travesty of poverty.

Because of their dependence on markets, it is a matter of luck [Zufälligkeit] whether even hard-working individuals can earn a living in civil society. But it is at the collective level that arbitrariness generates the most problems, in terms of the vicissitude of the market. For it is here, in the delicate web of interdependencies that arbitrariness and contingency generate the mass unemployment and poverty that concerns Hegel.

The contingency of the satisfaction [of needs] is present in the most diverse

manner in the mechanics of society's necessity, both with regard to the

changeability of the needs themselves and as a result of...the errors and illusions

that can be introduced into individual parts of the whole mechanism and can bring

it into disarray. [Werke 8: \$533]

Here contingency of consumer demand becomes relevant in its effect on the smooth operation of the economy. Free trade policies leave the coordination of supply and demand to market forces. In principle, Hegel favored loosening contemporary restrictions on trade and employment practices, but he argues that the contingencies of production and consumption generate economic disequilibria in civil society, leading to the collapse of firms and the loss of jobs. "When a branch of industry does especially well, many individuals enter it. But the need for products has its limits, and even if such an industry becomes overfilled, the individuals cannot see it; they join in and are ruined" [VPR III: 698].

What Hegel is describing here is the blindness and haphazardness of boom-and-bust market cycles.

As Hegel was well aware, laissez-faire economics treats the painful consequences of disequilibria as the market's way of correcting itself. Despite his appreciation for the analytic power of this economic perspective [\$189A; VPR IV: 487], Hegel has nothing but sarcastic scorn for the way in which laissez-faire talk of "market self-correction", as his analogy with the plague makes clear: "The plague ends too; it rights itself. But hundreds of thousands have perished of it; they're all dead. Everything has thereby also been straightened out again." [VPR IV: 625]. These market shifts occur so quickly that workers have little time to adapt, especially as a result of the specialization of their training, and they are thrown out of work and lose their livelihood. Hegel also saw causes of unemployment and poverty in long-term trends toward mechanization, heavily capitalized competition, and general market-saturation, but it is the periods of disequilibrium that are, rightly, his focus.

Whatever the causes, the resulting poverty generates a prima facie demand for serious change. This is true for impoverishing inadequacies at both the individual and the collective level, but I shall be focussing here on the collective level of the economy as a whole. At the individual level of the "besonderes Vermögen," Hegel seems to favor a familiar welfare package including public provision of minimal needs, assistance in locating work, and job training and education, especially as these are provided through the Korporation ${ }^{\mathrm{xi}}$ Hegel see the only genuine anti-poverty approach as one of ensuring that the economy provides jobs that pay a living wage, which is the task of ensuring that the collective Vermögen is adequate. ${ }^{\text {xii }}$

There is, then, a need for intervention in the economy, according to Hegel. Put in systematic terms, the dialectic generated by poverty in civil society leads away from the blindness and Zufälligkeit of unregulated market relations:

$[T]$ he more blindly [the particular interest] immerses itself in its selfish ends, the more it requires such regulation to bring it back to the universal, and to shorten and moderate both the dangerous convulsions and the length of the intervening 


\section{Anderson, "Hegel's Solution to Poverty"}

period during which these collisions are supposed to return, by a process of

unconscious necessity, to equilibrium. [§236R; translation revised].

The problem, then is contingency - blind chance. Within the individualistic framework of civil society, economic actors lack the necessary awareness of the interdependencies within which they are entwined [\$236]. The need, in essence, is for what Hegel calls "self-consciousness".

And in the process of achieving greater self-consciousness, the emergence of the public authority [Polizei] plays an important transitional role, for it is only at that point that the economy can be surveyed [VPR IV: 591, 600]

\section{THE FAILURES OF THE PUBLIC AUTHORITY: EXTERNALITY \& BAD INFINITY}

In his discussion of efforts on the part of the governmental bureaucracy [Polizei] to solve the problem of poverty, Hegel focusses on two broad strategies: direct intervention in the domestic economy and the development of foreign markets. Hegel saw both strategies destined to fail, and the reasons he had for thinking this failure inevitable suggest what, for him, a genuine solution to the problem of modern poverty would have to look like.

The first strategy involves a wide range of programs familiar from the history of Keynesianism and state socialism: production regulations, price controls, jobs programs, protectionism, and, more generally, measures aimed at regulating and moderating the vicissitudes of the marketplace [\$§231-249]. Although Hegel was a staunch defender of certain regulatory practices (and very clearly of the public authority's responsibility for the infrastructure), he argues that the public authority's way of overcoming the blindness and extreme particularity of civil society is "external" to the will of participants in the market [\$231, 236]. Individuals experience the public authority the way people often seem to experience taxation and regulation: as a bureaucracy whose purpose and policies are not understood or recognized as an expression
Anderson, "Hegel's Solution to Poverty" 10

of their will, even if they sometimes benefit from them. In part, this experience may disappear as members of civil society become reconciled with their society as a result of coming to understand that it is rational to have differentiated economic and political roles. ${ }^{\text {xii }}$ But it is also clear that Hegel is thinking of a set of public agencies that, by their nature, must operate on the basis of elite expertise and will thus always be somewhat alien to ordinary members of society. On this reading, Hegel is arguing that bureaucratic institutions are necessarily ineffective in combating poverty because of their essential externality. Given the motivational problems involved, a command economy is not the best strategy for fighting poverty. ${ }^{\text {xiv }}$ What this shows, in terms of the logic of Hegel's overall argument, is that poverty cannot be eliminated through external interventions, that is, by having the universal imposed. Hence the need, as we shall see, for the intermediate and more internal institution of the Korporation.

The second strategy is to find new markets, especially by encouraging international trade and colonization [\$§246-8]. As a structural solution, this approach is initially more promising, for it is aimed at increasing society's "general resources" by addressing what Hegel sees as the fundamental problem, namely, a lack of consumers: "The poverty of workers consists precisely in the fact that there are no takers for what they produce. There is too much capital present, and so more is produced than the nation can consume." [VPR 19: 199]. Like Marx, Hegel saw the development of the forces of production as in the driver's seat: in civil society, productivity

"....increases in an unendingly large proportion to consumer need, and thus in the end even those who work hard cannot earn their bread." [VPR IV: 612]. The only way out seems to be to find consumers in less-industrialized countries:

This inner dialectic of society drives it -- or in the first instance this specific societ $^{x v}$-- to go beyond its own confines and look for consumers, and hence the 
Anderson, "Hegel's Solution to Poverty" 11

means it requires for subsistence, in other nations which lack those means of

which it has a surplus or which generally lag behind it in creativity, etc. [\$246]

As Hegel emphasizes, the asymmetry is crucial. Colonies and other less-industrialized countries function as new markets only insofar as they are not able to produce the goods of which the mother country has a surplus. With regard to the American colonies, for example, Hegel thought that because American independence left the asymmetry of industrial development intact, it actually was all to the advantage of Britain. ${ }^{\text {xvi }}$ Colonization is thus not a generalizable solution to the problem of poverty, and it is clear, despite commentators' claims to the contrary, that Hegel realized this. ${ }^{x v i i}$

Hegel goes on to argue that international trade in general will not solve the problem of overproduction behind modern poverty. This may be surprising, since we can easily imagine symmetrical trading relations in which equally highly industrialized countries export "excess" goods and yet still provide consumer niches for the "excess" goods of other countries. And there is even some evidence that Hegel saw the internationalization of economies as offering some stability [VPR IV: 507f.]. Ultimately, however, the thought that this only postponed the crisis. Given that civil society is oriented towards limitless expansion, even a successful scenario, in which new markets are found, provides only the illusion of a solution: a country finds an export market for surplus products; this enables economic growth, which again leads to overproduction, and a new border must be crossed in order to secure a new market. And this matter of endlessly "going beyond oneself" [Übersichhinausgehen] is precisely the sort of fallacious thinking that

Hegel condemns as "bad infinity." The discussion of bad infinity in the Enzyklopädie contains a description of "flight" that perfectly describes the futile attempt to export the problem of overproduction:
Anderson, "Hegel's Solution to Poverty" 12

A limit is set, then surpassed, then yet another limit, and so on forever. We have here nothing but a superficial alternation that remains stuck in the finite. When one thinks one can free oneself from the finite by stepping into that infinity, then that is in fact merely the liberation of flight. But the one who flees is still not free, for in fleeing he is still determined by that from which he is fleeing. [Werke 8: $\S 94 \mathrm{~A}] .^{\text {xviii }}$

Similarly, attempts to solve the problem of poverty by boosting growth through trade ultimately remain trapped within the pointless pursuit of infinite expansion. The problem keeps returning.

Thus, despite the undeniable importance of the public authority in many regards, neither expert regulation of the economy nor growth in foreign markets can ensure that the general resources of a society will be adequate to prevent poverty. Within the logic of Hegel's account, the failure of the public authority is the failure of economic policy that lacks the internality and self-restraint essential to full ethical self-consciousness. And this is precisely what the Korporation provides.

Before turning to the role of the Korporation, it is worth taking stock of the plausibility of Hegel's views on the economy. It must be acknowledged that Hegel's talk of "overproduction", as a feature of an entire domestic economy, is at best misleading. For, as long as money is included as a commodity (which it is), overproduction as such is impossible. As Say's Law states, "Goods constitute the demand for goods." "xix If I make more shovels than anyone in my community wants, the price drops and suddenly shovels are a lot more affordable, so that more people will then buy them. The problem is thus not overproduction per se but rather the depression of prices in a given market and the resulting fact that I do not earn enough to live on. But that simply means that I should make something other than shovels - because otherwise, 
I'm just making something that no one really wants (unless the price drops close to zero). Price, after all, is a mechanism for determining what people think ought to be produced.

Of course, the disruption in my life is serious, and that is really where the suffering comes in. In line with this, it seems safe to say that Hegel's strongest point comes from saying that rapid fluctuations in supply and demand generate unacceptably high costs for those who are displaced by the fluctuations in employment.

\section{THE KORPORATION AND THE GEBILDETE CONSUMER}

Although its precise nature is much-disputed, the Korporation can be thought of as an intermediate institution or association that provides a form of community between that of the family and that of the nation. In Hegel's discussion, membership in a Korporation is a typically function of one's participation in a branch of industry - though not of one's class - but the activities of the Korporation include political and social activities alongside the economic ones. Several historical models are available, including the medieval guilds, the Sozialdemokratische Partei Deutschlands in the early 1900s, or the Dutch confessional zuilen ["pillars"] of the century preceding the Second World War. ${ }^{\mathrm{xx}}$ As these models suggest, the Korporation is supposed to provide a context for everyday cooperation and discursive interaction that generate a feeling of belonging as well as a heightened understanding of the rationality of one's social world.

Because of this more "internal" relation between the Korporation and its members, Hegel views the Korporation as better able to address the needs of the poor. This has often been noted, ${ }^{\text {xxi }}$ but the focus is usually on the way in which this more internal relation provides a respectful and supportive context for solidary aid: "Within the corporation, the help which poverty receives loses its contingent and unjustly humiliating character" [\$253R; cf. VPR19: 203, 206; VPR III: 709]. This is merely a matter of ameliorating poverty, however. If the
Korporation is going to play a role in actually addressing the causes of poverty, there has to be more going on here. And there is.

The moment of the Korporation marks the return of the ethical to civil society, for, a members of a Korporation, individuals have a heightened consciousness of shared goals an mutual interdependence:

The Korporation initially has the same function, the same purpose as the public authority, namely, the particular interest - not, however, as the object of a merely external ordering activity (as is the case with the public authority), but rather as the object of an activity that wills the universal, but in such a way that the individual himself participates in this activity.[VPR IV: 621; see also §255A].

In addition to the oft-noted transformation of ethical disposition this involves, this shift to more reflective participation of individuals in determining their conditions of life has significant politico-economic implications as well. And this is the crucial point. For the emergence of this new awareness raises the possibility of increased rationality of the economy by introducing attitudes toward of production and consumption in which individuals participate with greater understanding of how they are contributing to the common good [das Allgemeine]. ${ }^{\text {xii }}$

One way in which this happens is by the Korporation restricting the number of people who can enter its ranks and thus be productive in a particular industry. The basic idea here is that, in consciously limiting the number of people producing certain goods or services, the Korporation prevents wild fluctuations both in employment and production. Thus, when Hegel asserts that "the corporation has the right...to admit members...in numbers determined by the universal context" [§252], he is assigning the Korporation the task of assessing, within the framework of the economy as whole, how many people the industry can sustain. Stephen 


\section{Anderson, "Hegel's Solution to Poverty" 15}

Houlgate formulates Hegel's point here as follows:

[A] corporation can not only limit the number of people producing a certain type of product within society as a whole, but can also ensure that within the corporation production opportunities are equitably distributed and that manufacturers and traders do not try to undercut one another. In this way, the measures needed to prevent overproduction are taken by the producers

themselves, rather than by the state. This ensures not only that decisions about production are taken by people who understand it, but also that controls on the productive activity of members of civil society are self-imposed. ${ }^{\text {xiii }}$

Here it becomes clear in what sense the Korporation is able to accomplish what the public authority failed to do. By intervening in the economy "internally" and with an awareness of their place in the networks of production and consumption, members of Korporationen are better able to avoid impoverishment that results from producing more than the market can bear at decent prices. And they can do so, according to Hegel, without violating the principle that individuals have a right to choose an occupation that makes good use of their talents. ${ }^{x i i}$

There are limits to this approach, however, for simply limiting the number of employees in an occupation is not enough to restrict the uncontrolled expansion of production, particularly since Hegel traced the tendency toward overproduction not only to periodic swells of hiring, but also -- even especially -- to efficiency measures and mechanization [VPR IV: 612; VPR17: 138] More important for my purposes, it does not guarantee sustained consumer demand.

Again, as we have seen repeatedly, we come back to the issue of ensuring stable and adequate consumer demand so that the collective Vermögen remains high, thus guaranteeing enough jobs that pay a living wage. And here too the Korporation can play a role, in this case,
Anderson, "Hegel's Solution to Poverty" 16

by providing the context for the formation of more responsible consumer practices. Although this has not, to my knowledge, been discussed in the literature, I believe that Hegel thought that, as members of Korporationen, individual consumers can promote the common good -- they "will the universal" -- by spending their money in ways that increase the general resources [allgemeine Vermögen], thereby alleviating poverty.

There are several places where Hegel suggests this. To begin with, he emphasizes the economic importance and rationality of certain modes of consumption. "We can distinguish here between consumption that also contributes to the general resources and consumption that reduces the general resources." [VPR III: 618]. Or again:"A big spender benefits civil society more than someone who contributes the same amount to charity, because the first way is tied to the activity of others, the employment of their understanding." [VPR III: 615]. Especially in light of his criticism of conspicuous consumption, it becomes clear that Hegel has in mind an ethic of responsible consumption, one which involves the form of self-consciousness that, as we saw at the end of the previous section, is needed for moving beyond the limitations of the public authority. Among "ungebildeten Völkern," [uncultured peoples] he emphasizes, "there is a lack of consciousness of the way the use of my property is disadvantageous for others."[VPR IV: 591; see also the especially strong language at VPR IV: 475-7]. By contrast, the model of the rich doing good by consuming more is an example of a more general, responsible attitude toward consumption: responsible consumers understand their consumption as contributing to economic welfare and - to extend Hegel's thought here - in times of overconsumption and capital-shortage, these responsible consumers would presumably spend less and save more. The general principle, however, is that a society with stable employment patterns will be a society in which consumers put their money where the jobs are. 


\section{Anderson, "Hegel's Solution to Poverty" 17}

Hegel does not offer many examples, but contemporary experiences with heightened consumer consciousness shed some light on the possibilities. We are most familiar with consumer groups that are motivated by moral objections to brutal political regimes (divestiture from South Africa in the 1980s), inhumane labor practices (child labor in the handmade carpet industry), environmental degradation (tropical hardwoods), cruelty to animals (especially veal or frois gras), moral turpitude (movie studios that produce pornographic films), and so on. The model I see suggested in Hegel is different, however, for it focusses not on a moralization of consumer practices but rather a concern with the universal in a more purely economic mode. The point is that consumer preferences themselves would have to be mediated by an understanding of what current production patterns are and how one's consumer practices affect them. For example, if I am aware that a favorite restaurant is having trouble attracting business, I may frequent it more often to help keep it afloat. If a craze for this Christmas season's "hot" toy is leading to wild retail and production fluctuations, I may choose a different gift for a child. Or I may purchase goods that are produced by laborers earning a living wage, so as to resist the downward pressures on wages that come from uncertainty and fierce competition. In small ways, these choices help to support rational and stable growth in consumer demand, and insofar as this occurs, the general resources are increased.

There is a danger here of what could be called a "productionist" bias. This involves assuming current production patterns as given, and then requiring individual's tastes to adapt to the production. This is not only psychologically implausible, it is clearly much too one-sided for Hegel. A much more Hegelian picture is to say that both the productionist model and the economic liberal's model (according to which production patterns ought to adapt immediately and constantly to changes in consumer preferences) are each only half right. Though there is no
Anderson, "Hegel's Solution to Poverty" 18

point in producing something no one wants, there is also no point in disposing of the accumulated knowledge of established production patterns - and generating unemployment, displacement, and poverty in the process - for the sake of consumers' whims. For example, in a society in which many people are employed in building wooden houses and are highly skilled at it, it might make sense - as part of "willing the universal" - for consumers not to give in to a new fashion for brick houses. To dismiss the relevance of the existing production practices (as economists tend to do in treating these as irrational attachments to "sunk costs") $)^{x x}$ and to insist that production must always do the bidding of given preference is to succumb to a form of onesided thinking.

Whatever the details of how this ought to be done, it is clear that this attitude of what we could call the "responsible consumer" perfectly fits Hegel's model of the advance in rationality that he terms "self-consciousness", an advance that can only result from the transformative learning process he calls "Bildung." The concept of Bildung is crucial for understanding why self-conscious consumer practices are part of the development of civil society, and not a simple forfeiture of gains of subjective freedom. In the opening sections of "Civil Society," Hegel describes civil society as a process by which particularity is "educated" to and brought in line with universality through economic activity.

[In civil society], the individual is initially for himself; he is his own end; yet the satisfaction of his needs also involves others; in this way, the individual is dependent on the others, and must be oriented toward them; he must often sacrifice his particular will, for what matters is [not only] his own will but of bringing himself in accordance with others who are likewise situated [selbstische Anderen]. That is, he must distance himself from the particular. In civil society, 
the process [of education] is this erradication of the particular....[T] he uneducated

[ungebildete] man always reveals his particularity - now injuring, now offending.

To behave in a universal manner entails having consideration for what is

appropriate to the nature of the relations. [VPR IV: 484; cf. §187,R,A; VPR III

581-5]

But to say that, in civil society, the particular is educated to will the universal is not to say that individuals are swallowed up into a general will at the expense of their individuality, originality, and particularity. Especially with regard to matters that are of relatively little importance to society and the state, the "formal freedom" of caprice and personal projects has its place [§289R]. What this formative process does put an end to, however, is individuals' insensitivity to the welfare of others and to the common good, as well providing an understanding of how to avoid the bad infinity of the "indeterminate multiplication of needs, means, and pleasures" [§195]. ${ }^{\text {xxi }}$ Central to Hegel's account, then, is the idea that education produces an awareness of the impact of one's actions - including economic activities - on others. This consciousness of one's situation within webs of interdependence and the sense of responsibility that comes with it emerge only in a formative process. And the development within civil society that we have followed -- whereby the interdependence demanded by the market leads through a crisis of poverty and overproduction to the conscious willing of the universal (first by the public authority and then by members of Korporationen) - represents just such a developmental process [Bildungsprozeß].

For Hegel, the Korporation is the appropriate institution for this transformation of consumption practices for several reasons. In part the Korporation can play the role it does because of the community context it provides. Once an individual is assured recognition within the Korporation, the economically destabilizing need to prove himself through conspicuous consumption vanishes, xxvii and he must instead show his worth "through the manner in which he uses his wealth for his cooperative [Genossenschaft]" [VPR 19: 207]. How one spends one's money thus becomes an ethical matter. In this sense, the Korporation represents the "return of the ethical to civil society" [\$249]. More generally, however, the Korporation provides the context for ongoing, intersubjectively mediated socialization of individuals as responsible agents, in particular the conscious attention on the part of individuals themselves to the networks of interdependence within which they move. Within the ethical framework of the Korporation, the distinction between the sort of consumption that contributes to the common welfare and the sort that does not becomes the basis for a principle that members of the Korporation can use in guiding their own lives and in according recognition to others. What we have here, then, is a subjective appropriation of the logic of "Vermögen" ["resources"] and, thus, an "internalization" of the coordinating function that the public authority tried to achieve externally. It is the Korporation that makes this possible, for it is only with the emergence of that form of community that individuals in civil society become able to relate to their own needs and desires in a way that is mediated by shared concerns. None of this needs to involve explicit, moral deliberation about what the right thing to do is. As an instance of the ethical substantiality that constitutes ethical life, it would come to be second nature or habitual [cf. $\S 151,151 \mathrm{~A}]$ that responsible consumers consider the impact of their practices. And that second nature is acquired and sustained through the socializing context of the Korporation

The notion of the gebildete, responsible consumer I have been describing can be clarified with a parallel in contemporary discussions of the role of political associations and the public sphere within a model of deliberative democracy. ${ }^{\text {xxvii }}$ In the context of political will-formation, the role of intermediate institutions is to offer a context in which arbitrary, subjective political 
opinions of individuals are educated or "gebildet" in a way that allows for both stability and flexibility. The rationality afforded by a reflexive moment of public deliberation provides protection against both the wild political vacillations of plebiscitary democracy (the political corollary of laissez-faire economics) and the rigidity of expert-driven democracy (the political corollary of a command economy run by the public authority). This is not something that happens by itself. It requires a public context. And thus we can imagine the Korporation playing a parallel role in shaping responsible practices of consumption.

One difficulty for the interpretation I have been offering is that, while the control of production naturally falls to the Korporation given that its membership is based on shared connection to a specific branch of industry, the same cannot be said for consumption. ${ }^{\text {xxix }}$ One response is to say even if we assume that corporate membership must be industry-based or profession-based, the Korporationen serve as general schools of virtue, inculcating practices of consumption that are good for the whole economy, rather than only for one's own Korporation. On this model, the Korporationen function to instill a sense of economic citizenship and civility, just as they do for the political realm. Alternatively, the Korporationen can be understood more broadly, as including social and cultural associations, something suggested by Hegel's discussion of churches [§270R]. This would then allow for membership in multiple Korporationen: one is a Catholic and a lawyer and a member of a coop for buying organic food and a user of Apple computers - each of which offers an institutional context of ethical socialization [Bildung], but in a way that is geared toward protecting specific interests that one shares with the interests of one's Korporation. Either way, we can certainly envision associations that serve to develop, inculcate, and reenforce patterns of action - in this case, of consumption - that have the potential to help stabilize the economy.

\section{CONCLUSION}

Whether a transformation in practices of consumption could actually be realized and whether it would end poverty is a very open question. ${ }^{x x}$ My claim here, however, is that Hege had more of a sense than is usually thought of what the components of a solution to poverty would have to be. His published texts are clearly pessimistic about the prospects for such a solution, but particularly in the lectures that he gave toward the end of his life, he seemed to hold out a vision of a world in which poverty would no longer do that damage that he saw it doing in England.

Even as a proposed reading of Hegel, however, there are several issues yet to be resolved. First, more would need to be said about the model of the responsible consumer, its psychological feasibility, its compatibility with the decentralized, complex conditions of market economics, and its relation to the form of ethical freedom that Hegel calls "autonomy". Second and relatedly, more would need to be said about the character of the Korporation in which this responsible consumer would be found and formed, particularly regarding the discursive and deliberative character of this form of associational life. Finally, and perhaps most importantly, the residual particularity of the Korporation needs to be addressed. ${ }^{\text {xxi }}$ Hegel saw the Korporation as in danger of becoming mired in the myopic defense of its own interests and as thus in need of integration into more universal moment of ethical life, namely, what Hegel calls the "state" [§289A]. The key, then, is to show that the logic of Hegel's argument demands a model according to which the Korporation internalizes some of the self-consciousness and universality of the moment of the state without returning to the external controlling mechanisms of the Polizei or exclusively top-down control by the state. ${ }^{\text {xxxii }}$

However much may still remain unclear at this point about the details, what I hope to 
have made plausible is that, on Hegel's view, any solution to the problem of poverty would have to pay attention to practices of consumption and that one of the potentials for increased

rationality afforded by the Korporation is for the formation of more self-conscious, sittlichen, and responsible consumers. ${ }^{x x \times i i i}$
ABBREVIATIONS OF WORKS USED

References in brackets that include on a section number -- e.g., "[§245]" -- are to Hegel's Rechtsphilosophie. English translation: Elements of the Philosophy of Right, trans. H.B. Nisbet and ed. Allen W. Wood (New York: Cambridge University Press, 1991). Citation is by paragraph number and, when relevant, "R" for Hegel's marginal "Remarks" and "A" for the "Additions" drawn from lecture notes.

Werke $=$ Hegel: Werke: Theorie Werkausgabe (Frankfurt: Suhrkamp, 1970), volume and page number.

VPR17 = Die Philosophie des Rechts: Die Mitschriften Wannenmann (Heidelberg 1817-1818) und Homeyer (Berlin 1818-1819), ed. K.-H. Ilting (Stuttgart: Klett-Cotta, 1983).

VPR19 = anonymous transcription of the lectures from 1819-1820, published as Philosophie des Rechts: Die Vorlesung von 1819/1820, ed. Dieter Henrich (Frankfurt: Suhrkamp, 1983); VPR III = H.G. Hotho's transcription of 1822-1823 lectures, published in Vorlesungen über Rechtsphilosophie, vol. III, ed. K.-H. Ilting (Stuttgart: Frommann-Holzboog, 1974)

VPR IV = K.G. von Griesheim's transcription of the 1824-1825 lectures, published in Vorlesungen über Rechtsphilosophie, vol. IV, ed. K.-H. Ilting (Stuttgart: FrommannHolzboog, 1974).

Note that the orthography and spelling of the lecture notes is often nonstandard. All translations from the lecture notes are mine. 
iThe recently published notes from Hegel's lectures on the Philosophy of Right (VPR I-IV; VPR 17; VPR19) provide crucial evidence for the interpretation defended here, and I shall be making extensive use of them. These student transcriptions represent a reliable source for Hegel's views and are, unlike the version published during Hegel's lifetime, free from the mark of government censors. Although some of this material has been available in the "Additions" that Hegel's student Eduard Gans included in his posthumous edition of the Philosophy of Right, Gans's selections are partial and frequently do not contain crucial passages. This is not to say that the views expressed in the notes cannot be found in the published text but rather that they can sometimes be discerned best in light of the articulations found in the lecture material. (Note that the translations of the lecture material quoted here is mine.)

iiShlomo Avineri, Hegel's Theory of the Modern State (Cambridge: Cambridge University Press, 1972), p. 154. For a further discussion of the uniqueness of poverty as a problem that Hegel does not solve, see Michael Hardimon, Hegel's Social Philosophy: The Project of Reconciliation (New York: Cambridge University Press, 1994), 236-50.

iiiIn addition to Avineri, see also Allen W. Wood, Hegel's Ethical Thought (New York: Cambridge University Press, 1990), 242; and J. Donald Moon, "The Moral Basis of the Welfare State," in

Democracy and the Welfare State, ed. Amy Gutman (Princeton: Princeton University Press, 1988), $28-30$

ivRaymond Plant, "Hegel on Identity and Legitimation," in The State and Civil Society: Studies in Hegel's Philosophy, ed. Z.A. Pelczynski (Cambridge: Cambridge University Press, 1984), 239-43, Thomas E. Wartenberg, "Poverty and Class Structure in Hegel's Theory of Civil Society," Philosophy and Social Criticism 8 (1981): 169-82; and Bernard Cullen, Hegel's Social and Political Thought (New York: St. Martin's Press, 1979), 85-96.

v"As such, the family is initially closed in on itself, without a need for outward integration." ["Die Familie als solche ist zunächst in sich beschlossen, hat kein Bedürfniß der Vereinbarung nach 
Außen"] [VPR III: 623].

viln light of Hegel's own views on women, I shall "he" as the pronoun for such terms as "citizen" and "individual".

viilt is important not to think of "resources" ["das Vermögen"] necessarily in terms of financial or property assets. Unfortunately, the earlier Knox translation uses "capital" or "wealth," which, for starters, blurs Hegel's distinction between "Vermögen," "Kapital," and "Reichtum." Nisbett's recent translation corrects this by using "resources" throughout, but even this can still mistaken suggest that it is something that can be possessed in the form of income or wealth. One interpreter who understood this well is Paul Vogel: "The lasting general resources of society are thus not the sum of the natural treasures and exchangeable goods, not at all anything material and dead, but rather the sum of living laboring energies that are guided by a rational intellectuality and which, in mutual dependence, enhance one another's productivity" [Vogel, Hegels Gesellschaftsbegriff und seine geschichtliche Fortbildung durch Lorenz Stein, Marx, Engels, und LaSalle (Berlin: Pan-Verlag Rolf Heise, 1925), 25].

viiiFor this reason, Nisbet's translation is misleading here. In the passage "The possibility of sharing in the universal resources -- of holding particular resources..." [\$200], the phrase "of holding" is neither contained in nor required by the original German. It has the unfortunate effect of forcing a reading of das besondere Vermögen as akin to property.

ix

Manfred Riedel, Bürgerliche Gesellschaft und Staat bei Hegel (Neuwied: Luchterhand, 1970) and Joachim Ritter, Hegel und die französische Revolution (Frankfurt: Suhrkamp, 1965).

XSee especially §185. For an excellent recent discussion of how Hegel's notion of freedom

demands an approach to economics that goes beyond arbitrary choice, see Will Dudley, "Freedom and the Need for Protection from Myself," The Owl of Minerva 29 (1997), 39-67.

xiln this connection, it is important not to misunderstand some of Hegel's harsher claims about "leave the poor to their fate and direct them to beg from the public" [§245R; Hegel's most revealing discussion of this is at VPR IV: 612]. What Hegel wishes to prevent is able-bodied individuals -and men in particular, who are assumed to be the breadwinners -- developing the attitude that they have claim-rights to assistance without any correlative duties: "Since society is obliged to feed its members, it also has the right to urge them to provide for their own livelihood" [ $\$ 240 \mathrm{~A}$; on duties and rights, see §155]. The refusal to recognize this is what Hegel calls the "rabble mentality" [see esp., VPR IV: 609]. Note that the rich can also have this mentality [VPR IV: 608].

As long as aid is not unconditional, it is not clear that Hegel must see direct aid to the poor as a problem. See also Nobert Waszek, "Hegels schottische Bettler," Hegel Studien 19 (1984), 311-316; Hardimon, Hegel's Social Philosophy, 238-9; and Wood, Hegel's Ethical Thought, 250-4.

xiiThe more direct approach of providing government jobs is rejected by Hegel, on the grounds that they only exacerbate overproduction [\$245]. But Hegel is too quick here, for this objections is true only of jobs programs increase production in a market that is saturated. The situation was quite different, for example, for W.P.A. programs of Depression-era America put people to work doing things that would not otherwise have been done, like building trails in national parks and producing public art work.

xiiiHardimon, Hegel's Social Philosophy, 206-9.

xivWolfgang Kersting, "Polizei und Korporation in Hegels Darstellung der bürgerlichen Gesellschaft," Hegel-Jahrbuch 1986, p. 378.

$\mathrm{xVThere} \mathrm{is} \mathrm{reason} \mathrm{to} \mathrm{think} \mathrm{that} \mathrm{the} \mathrm{reference} \mathrm{to} \mathrm{"this} \mathrm{specific} \mathrm{society"} \mathrm{is} \mathrm{a} \mathrm{reference} \mathrm{to} \mathrm{Britain.}$ Hegel traced Britain's prosperity to her unique circumstance as the dominant industrial economy in the world. In an insightful remark on the use of England as an example in defense of laissez-faire economics, Hegel points out that "...comparisons are often distorted, and rarely are all factors considered; England has the whole world as a market and as a basis for colonization - that is the major factor" [VPR IV: 625; cf. VPR III: 711]]. See also A.S. Walton's discussion of this passage in 
"Economy, Utility, and Community in Hegel's Theory of Civil Society," in Z.A. Pelczynski, The State and Civil Society, 259.

xvi"North America, for example, liberated itself, and this turns out to have been of greatest advantage to England, for although North America has made itself into a state, it still has many needs that it cannot provide for on its own, since it is still largely an agricultural state." [VPR III: 707; cf. §248A; VPR19: 199; VPR IV: 615f; Werke 12: 114]. Independence did, of course, release the Americans from what Hegel saw as unjust restrictions on industrialization and trading relations [VPR19: 198].

xviilt is striking how many commentators attribute to Hegel the view that colonization is a solution to the problem of poverty. Raymond Plant, for example, states that "Of course it is well known that in the Philosophy of Right Hegel argued that the problem of poverty required a solution which involved imperialism" ("Hegel on Identity and Legitimation," 240f.). The fact that colonization involves a "return to the family principle" makes it undeniable that this is a best a postponement of the problem, since the family principle always gives way to civil society.

xviiiWith regard to the "infinite" economic expansion of civil society, see VPR IV: 612. This point has also been noted by Paul Chamley: "According to Hegel, interdependence creates serious

dangers for the provision of consumers as well as the income of workers. The principle vice of this system is the lack, within itself, of a principle of its equilibrium. Its law is that of bad infinity, of linear progress toward infinity"[Paul Chamley, "La doctrine économique de Hegel d'après les notes de cours de Berlin," in D. Henrich and R.-P. Horstmann (eds.) Hegel's Philosophie des Rechts: Die Theorie der Rechtsformen und ihre Logik (Stuttgart: Klett-Cotta, 1982), 135].

XixFor an excellent overview, see Mark Blaug, Economic History in Retrospect, $4^{\text {th }}$ ed (Cambridge: Cambridge University Press, 1985), ch. 5.

xxOn the social democrats, see Carl Schorske, German Social Democracy 1905-17 (Cambridge,

Mass.: Harvard University Press, 1983). On the Dutch confessional "pillars", see, e.g., Siep
Stuurman, Verzuiling, kapitalisme en patriarchaat (Nijmegen: SUN, 1983). Regarding Hegel's attitude toward the guilds - which were typically much more than economic organizations - it is important to note that, although he had criticisms of the guilds, the most damning lines on the topic ("the miserable guild system", and the last two sentences of $\$ 255 \mathrm{~A}$ ) are not actually found in the lecture notes from which that "Addition" is supposedly taken, and cannot be found in any of the published lecture notes.

xxiFor a good discussion of this point, see Robert R. Williams, Hegel's Ethics of Recognition (Berkeley: University of California Press, 1997), ch. 11.

XxiiFor a discussion of this shift as a matter of grasping connections that were already in place but not fully understood, see Raymond Plant "Hegel on Identity and Legitimation," op. cit. My own sense is that Plant's reading puts too much weight on the shift in thinking and not enough on the transformation of customs and practices established in the Korporation, though these are arguably inseparable for Hegel.

xxiiiStephen Houlgate, Freedom, Truth, and History (London: Routledge, 1991), 117.

XxivVPR IV: 624. For Hegel, the freedom of occupational choice is the freedom to choose a manner of participating in the economy that allows one to fit into a complex network of interdependent relations: "The individual will pursue what he can and the choice is up to him, as a matter of his arbitrary choice [Willkür]; on the other hand, will not only do what he can, but has the essential end of thereby securing subsistance for himself; that's supposed to be the outcome..... One often gets stuck on the formal matter of the desire to pursue [a particular occupation]; what is crucial, however, is the other side, that the goal be met; and that is what the Korporation does." [ibid].

XxvFor an interesting discussion of "sunk costs, see, Elizabeth Anderson, Value in Ethics and Economics (Cambridge, Mass.: Harvard University Press, 1993), 34-6.

xxviIn this passage, Hegel says that just as this indeterminate expansion of needs "has no limits" 
the same can be said of "the distinction between natural and educated interests" [\$195]. In his

translation of this passage, Nisbet follows Ilting [VPRII: 644] in reading (for the word translated as "educated") "gebildetem" rather than the Suhrkamp edition’s "ungebildetem". Both readings are, however, mistaken. The passage should read "eingebildetem" [artificial or fanciful], which is the phrase found in the parallel passage in the Griesheim notes [VPR IV: 493]. One reason for preferring this reading is that it more easily explains lexigraphically Gans's misreading of "un-" for "ein-". For my purposes, however, the important point is that this keeps open the space for understanding educated needs as the Aufhebung of natural and artificial needs, and as a form of consumer desires that is not subject to "bad infinity".

xxviiPhilosophy of Right, §253,R; VPR 19: 206f. For good discussions of this point, see Dudley,

"The Need for Protection from Myself," 52f.; Iring Fetscher, "Zur Aktualität der politischen

Philosophie Hegels," in Hegel-Bilanz: Zur Aktualität und Inaktualität der Philosophie Hegels, ed. Reinhard Heede and Joachim Ritter (Frankfurt: Vittorio Klostermann, 1973), 212; and Robert

Williams, Hegel's Ethic of Recognition, ch. 11.

xxviiiSee, for example, Jürgen Habermas, Between Facts and Norms: Contributions to a Discourse Theory of Law and Democracy, trans. William Rehg (Cambridge, Mass.: MIT Press, 1996); James Bohman, Public Deliberation (Cambridge, Mass.: MIT Press, 1996); and James Fishkin,

Democracy and Deliberation (New Haven: Yale University Press, 1991).

xxixI would like to thank Stephen Houlgate for raising this issue.

XXXWood, for example, suspects that it is "utopian" to think that corporate civil society can stabilize the economy without undermining the subjective freedom made possible by market-based civil society (Wood, Hegel's Ethical Thought, 242).

xxxiThere is, of course, a very real issue of how the Korporationen are to relate to one another, and in this sense they are not fully concerned with the universal. This objection is pressed, for example, by Richard Teichgraeber, "Hegel on Property and Poverty," Journal of the History of Ideas 38
(1977): 59-62.

xxxiiIn this connection, Robert Williams proposed reading of the state as a "social organism" is particularly fruitful (Williams, Hegel's Ethic of Recognition, ch. 13).

xxxiiiFor comments on and discussion of earlier drafts, I would like to thank Rüdiger Bittner, Jim Bohman, Susan Buck-Morss, Will Dudley, Raymond Geuss, Joe Heath, Axel Honneth, Stephen Houlgate, Pauline Kleingeld, John McCumber, Kevin Olson, Thomas Schmidt, Kevin Thompson, Allen Wood, and members of the audience at the Hegel Society of America meeting in Athens, Georgia. 